\title{
Critical trends of
}

12.

citizen participation in policymaking.

Insights from

Portugal

Roberto Falanga 


\section{INTRODUCTION}

Worldwide, citizenry mistrust in governments, governors, and international financial markets is posing great challenges to democracy. Disaffection grows against the spread of ethnic, political, and religious intolerance, paired by the rise of populist instances that threaten human and civil rights worldwide. Within this turbulent scenario attempts to recover the relationship between citizenry and political institutions have been urged by a wide range of agents having different financial and political influences over the state.

Mechanisms of citizen participation in policymaking have emerged as one of the instruments aimed at strengthening democracies. In the last three decades participatory processes have spread around the world, mainly in the form of participatory budgets. In this span of time, discourses and practices of citizen participation have changed while models of governance have been demanded to effectively adapt to the global scenario. Surprisingly, changes in citizens' participation and their relations with the global political and financial framework have been weakly addressed by scholars. The intricate relationship between global agencies influencing national and local governments in the enactment of citizen participation is the object of analysis in this chapter.

To explore this issue, light will be shed on the convergence of international and transnational agencies on the promotion of a global citizen participation agenda that matches and reproduces some of the neoliberal values. The dissemination of participatory processes is approached from a critical perspective by pointing out three main trends emerging from this global convergence: the detachment oflocal participatory practices from global issues; the shift toward technocratic approaches in detriment to political-oriented practices; and the scarcity of evaluation in contrast to the mushrooming of pilots. In the second part of the chapter the expansion of citizen participation in Portugal will be analysed in light of this framework. Considering the high number of participatory processes currently implemented in the country and celebrated internationally, the discussion will contrast national evidence with the three global critical trends in citizen participation. 


\section{CITIZEN PARTICIPATION: A CRITICAL APPROACH}

Spaces for citizen participation in policymaking aim to create institutional channels for civil society to enhance the effectiveness of democratic governance (Cornwall 2004). While evidence shows that institutional designs (Smith 2009) and policy areas covered by participatory processes can vary considerably (Barnes et al. 2007; Gaventa and Barret 2010), the improvement of public policies and services is often pursued as a normative goal of democratic values' enhancement. As such, participation is promoted as both instrument to solve problems in need of wider consensus, and empowering practice for civil society (Fiorino 1990). This ambition characterizes current discourses on participation, and recalls early practices in the United States between the 1960 and 1970s (Pateman 1970; Arnstein 1971; Rosenbaum 1976), as well as goals of policy effectiveness and social empowerment promoted in the 1980s, within international projects for poverty reduction, mostly funded by the World Bank (wB) in developing countries (White 1996; Mohan and Stokke 2000; Brown 2004).

The initiation of participatory budgeting in Latin America at the end of the 1980s should be considered as a third historical phase for citizen participation and a milestone of ongoing dissemination. In emphasizing goals of economic redistribution and administrative reforms, participatory budget in Porto Alegre shined a light on the need for social justice and state reform in Brazilian cities (Avritzer 2006). The success of the Porto Alegre model relied on a complex institutional design of representative (via citizen delegates) and direct citizen participation at multiple levels, and was actively pushed forward by the Workers' Party (Partido dos Trabalhadores) in local authorities as well as, from 2002 to 2016, in the federal government. ${ }^{1}$

Meanwhile, after the "Washington Consensus" was agreed by the wB and International Monetary Fund (IMF) in the late 1980s, the UN and OECD were also converging, together with the $\mathrm{WB}$, on the importance of participatory programmes as a device to improve new models of governance worldwide. Phenomena of growing electoral abstention and mistrust toward political institutions became evident throughout the 1990s, and the fall of traditional

1 In Porto Alegre, the decentralization of decision-making power was accompanied by, inter alia, the creation of "community facilitators" in every local administrative department, and the institution of a new municipal council of the budget (Smith 2009; Baiocchi and Ganuza 2016). 
participation in associative groups and unions challenged the legitimacy of political institutions in the $\mathrm{EU}$ (EU, 2001). Against this backdrop, between the end of the 1990 s and the early 2000s, not only did participatory budgeting raise the enthusiasm of post-communist parties and alter-globalist activists in the World Social Forums, but also international and transnational agencies sensed the appeal that citizen participation had for the promotion of the new governance model (EU 2001; UNDESA 2008; OECD 2001; 2009).

The promotion of new governance models in the late 1990 s was consistent with an emerging conception of civil society as the new "stakeholder" of the public good (DeLeon 1992; Dryzek 2010). This conception relied on the need to shift from a vision of citizens as customers, rather than mere beneficiaries of the State, supported by new public managerial oriented reforms between the 1980s and the 1990s (Bryson et al. 2014). New governance compelled the adoption of new values and mechanisms seeking to decrease hierarchical and bureaucratic blueprints and enhance the inclusion of private and social actors in decision-making. The transference of public competencies in decision-making to civil society meant including market-driven and notfor-profit agencies on the supply-side of policies on behalf of the state or in partnership with it. The repositioning of civil society between the "global market" and the "minimal state" (Bailey and Pill 2011; Eder 2014) challenged democratic governance, as private and public actors were now called upon to rethink forms of corporatist bargaining with the state (Balbona and Bebega 2015).

The recognition of citizens as owners of civic knowledge and rights made a case in point on the opportunity to include them in decision-making (Roberts 2002). The promotion of consultative mechanisms with civil society, as a way to ensure broader consensus on policy solutions, lowered criticisms against consumeristic drifts of new public management reforms and prepared the ground for a new participation-centred discourse (Barnes et al. 2007; Bryson et al. 2014). The change in discourses and practices of citizen participation within the current political and financial framework suggests that the intricate relation between global agencies and states should be understood in light of the convergence of opposite narratives - that of the radical left in the World Social Forums and that of wB, European Union (EU), Organization for Economic Co-operation and Development (OECD), and United Nations (UN) - started at the end of the 1990s and 2000s (Dagnino 2004; Leal 2010; Lee 2015). 
Some scholars viewed the incorporation of citizen participation in the new governance model as the strategy to decrease the countervailing discourse on social injustice and state inefficacy, in favour of political institutions' (re)legitimization (Sintomer 2005). This shift led to the conceptualization of participation as a device for good governance, which opened the doors to the reinforcement of values of effectiveness and efficiency. However, according to some thinkers, it essentially meant branding the neutralization of political spaces in the name of neoliberalism (Cornwall 2004; Linke 2009; Hoppe 2011; Moini 2011). According to Jessop (2002), the evidence that citizen participation was used to compensate for the inadequacies of the global market is that it escaped from questioning the rules of neoliberalism in the global market. This convergence was also seen as a strategy for further market deregulation (Mohan and Stokke 2000), and further depoliticization of communities' struggles (Miraftab 2009). Inclusion of social actors in policymaking was seen as the way to legitimize elites' interests, while concealing (hence making less accountable) decision-makers' agendas (Swyngedouw et al. 2002; Hajer 2003).

The incorporation of participation into the neoliberal script recalls the convergence of multiple agents of transformation. National and local administrators have shown different degrees of ownership and autonomy in designing participation, as also transnational and international agencies should not be considered as monolithic in their attitude (Boughton 2003; Nielson et al. 2006; Goldfrank 2012). Acknowledging the complex and multiscale frame of participatory practices enacted worldwide, as well as the good results that many of them have achieved in terms of policy enhancement and/ or democratic empowerment, the next sections focus on critical trends from the convergence of neoliberalism and citizen participation.

\section{CRITICAL TRENDS OF CITIZEN PARTICIPATION:}

AN INTERNATIONAL OUTLOOK

The influence of international and transnational agencies on the implementation of a neoliberalism-friendly version of citizen participation has led to the emergence of critical trends. Scientific literature highlights a broad range of issues, and the following sections explore three main trends: the way the local scale favours the detachment of citizenship from global issues; the growth of technocratic approaches in contrast to ambitions of political change; and the scarcity of evaluation against the burgeoning of accountable pilots. 
LOCAL PARTICIPATION

Recent data show that global population is increasingly concentrated in urban contexts and that cities currently contain more than half of the world population (UN 2014). Global cities are repositioned on a highly competitive landscape as they are the outpost of financial, political, and social strategies driven by international finance (Bailey and Pill 2011), while demanded to strengthen democratic values and mechanisms. Local authorities are called upon to effectively act on issues that, in several cases, reflect and reproduce global forces. Whenever demanded to engage, local communities are also requested to be flexible, self-empowering, and proactive in solving issues, although these often exceed their actual capacity to tackle them (Jessop 2002; Swyngedouw et al. 2002; De Vries 2016).

The promotion of new urban agendas oriented toward the engagement of local communities within a framework in which international finance has a key role in influencing democracy posits great challenges. Criticism in this field of study says that local participation is often detached from wider discussion and understanding of the global order, or even minimizes the effects of neoliberalism on local democracy. Participatory practices tend to narrow deliberation around technical, and more often than not, short-term issues (Moini 2011). The "insulation" from the global framework is functional to reduce and neutralize the potential of conflict in decision-making (Mohan and Stokke 2000). This neutralization is often supported by discursive devices aimed at individualizing responsibilities (i. e. local agents are put at the centre of the arena with little provision of information on entrenching interests from other spheres of decision) and "romanticize" community life (i.e. social, demographic, and economic diversity of local communities is disguised as homogenous).

TECHNOCRATIC PARTICIPATION

The opening of wider margins to interest and organized groups has provided citizen participation with powerful symbols of public legitimacy. After the Porto Alegre participatory budget was lauded as best practice by UN Habitat in 1996, the international debate shifted the focus from goals of state reform and social justice to procedures and technical arrangements for citizen participation (Ganuza and Baiocchi 2012). This shift was broadly supported by local actors (Linke 2009) and, likewise, the globalization of participation technology and packaging amplified this trend. 
Transnational and international agencies have led the dissemination of techniques and tools, while supporting knowledge transfer among practices. From a critical perspective, the spreading of recommendations and toolkits for good participation has been one of the most impactful neoliberal strategies in this domain (Chavez 2008). Their role has helped to dilute the political orientation of citizen participation toward goals of social justice and state reform, toward a neoliberalism-friendly version. This shift is critically addressed by Leal (2010) in these terms: "[o]nce purged of all the threatening elements, participation could be re-engineered as an instrument that could play a role within the status quo, rather than one that defied it" (Leal 2010, 95).

Participation technology and packaging has often overemphasized the adoption of the right tools and techniques in detriment to critical reflection on societal change. The rhetoric of "easy" consensus building between local backers with the poor and marginal sectors of society has often shadowed social conflict. On this, Cornwall (2008) says that "although the term itself evokes a warm ring of inclusion, 'participatory' processes can serve to deepen the exclusion of particular groups unless explicit efforts are made to include them" (Cornwall 2008, 277). This point is corroborated by Brown (2004), who warns about the trivialization of participatory methods into the sequence of neutral brainstorming, in which major stakeholders are invited to "easily" agree on their interests (Brown 2004).

\section{NON-EVALUATED PARTICIPATION}

Evidence on the effectiveness of participatory processes continues to be scattered and the debate on criteria and measures remains almost nonexistent. Scarcity of scientific debate and practice of evaluation in this domain is often linked to the hurdle for rigorous and comparable evaluation before the complexity of the concept and the multiplication of forms through which participation can be implemented in different contexts. As Carpentier (2016) summarizes "[t]he abundance of concepts involved (and invoked) in participatory processes produce a level of analytical complexity that is hard to cope with, also from a researcher's perspective" (Carpentier 2016, 77). Another reason behind the scarcity of evaluation calls upon trends to hide political agendas behind the rhetoric of democratic innovations (Rosener 1978). More pointedly, citizen participation has often become the instrument for political, economic, and social elites to reinforce predefined agendas with renewed legitimacy. 
If evaluation is scarce, the dissemination of participatory processes continues to grow, together with the "market" of professionals and experts, often supported (or hired) by international institutions (Lee 2015). The multiplication of one-off local practices that barely provide comparable evidence of effectiveness deserve suspicion (Mosse 2001; Lee 2015; Bouchard 2016). The "pivotal" age of participation has been accompanied by a general lack of evaluation and, more in general, institutional frameworks in favour of temporary agreements and covenants. The lack of institutionalized relations between deliberative procedures, representative bodies, and their standard processes of decision-making and evaluation should not be underestimated (Hoppe 2011). Dependence on political willingness and, hence, on turnover and timings imposed by electoral cycles is likely to be exacerbated without institutional embeddedness.

\section{PORTUGAL: THE SOCIO-POLITICAL FRAMEWORK OF CITIZEN PARTICIPATION}

Public decision-making and the economic system in Portugal are essentially organized through national and local authorities. This binary system oversees regional intermediation, confirming historical state centralization and control over national economics (Teles 2016). Whereas mechanisms of direct democracy are issued bylaw, participatory democracy principles are presented in the national Constitution in support of representative and direct democracy (art. 2,9/c, 263$265,266,270$ ). At the local level, representative democracy mechanisms are coupled by opportunities for citizens to directly voice into decision-making via referendums, forms of direct consultation with the municipal assemblies, local association, and civic lists (De Sousa and Maia 2017).

The engagement of civil society in the design and implementation of public policies recasts some paramount initiatives experienced in the aftermath of the Carnation Revolution, such as the "Serviço de Apoio Ambulatório Local SAAL" led by architects and citizens between 1974 and 1976 for the collective design of social housing. Whereas the last 30 years witnessed the slow decrease of grassroots self-organization, the recent success of participatory budgets and the like has been countertrending. Implemented from the mid-20oos on (Dias 2013), and despite degrees of discontinuity in space and time (Alves and Allegretti 2012), the expansion of participatory processes in Portugal is today 
distinguished at the international level. The country currently hosts more than 180 initiatives distributed between municipalities and parishes, which is the highest rate in the world when considering the ratio between processes with the 308 municipalities and 3092 parishes. Along with this, the implementation of the national participatory budget in 2017 , allocating 3 million euros for the participation of citizens, and its second edition in 2018 with an increased amount of 5 million euros, further marks a world record for Portugal. ${ }^{2}$

Since the mid-200os the growth of citizen participation in policymaking has become a case in point in Portugal, Spain, and Italy (Font et al. 2014). These countries were especially affected by the recent financial crisis and, against risks of contagion, the Portuguese government agreed on the provision of a bailout package of 78 million euros under the supervision of IMF, EC, and European Central Bank (ЕСв). The intervention of the "Troika" was argued to reflect the high vulnerability of the country to the effects of the global crisis. The three mainstream parties - Socialist Party (PS), Social Democratic Party (PSD), and Popular Party (CDS-PP) - agreed to consolidate domestic finances and improve international competitiveness. ${ }^{3}$ The Memorandum of Understanding (MOU) in Portugal was preceded in 2010 by the attempt of the socialist government led by José Sócrates to pass austerity measures, which led to a U-turn from expansionary and countercyclical fiscal measures (Accornero and Pinto 2018; De Giorgi et al. 2015). Between 2011 and 2014 the implementation of the economic adjustment programme under the Mou imposed significant procyclical fiscal consolidation measures, in line with the bailouts provided to other countries in the same period (Ireland, Greece, Cyprus, Spain).

Compared to countries like Spain and Greece, social mobilization against the austerityin Portugal wasweaker and, according to Caldas(2012), characterized by increasing alienation from the political class, perceived as corrupt and dishonest.

2 In 2017 an additional national measure was launched for the young sector of society: the National Youth Participatory Budget, implemented between October and December with a share of 300,000 euros, and similar guiding rules to the NPB (www.opjovem.gov.pt).

3 The package, with an EU-share of 52 billion euros, represented the third IMF intervention in Portugal (the first in 1979 and the second in 1983), and was aimed at recovering low economic growth, high levels of public debt, and international competitiveness. The assistance was made conditional on the implementation of policy reforms, internally monitored by the special governmental unit ESAME. The programme included overruns on goods and services, with tax hikes and salary cuts for public servants, including a two-year suspension of $13^{\text {th }}$ and 14 th monthly wages and pensions eventually revoked by the Constitutional Court. 
Moury and Standring (2017) explain that alienation of grassroots movements and self-organized groups, especially of professional bodies, occurred because austerity was presented as a fait accompli, with narrow margins for revision. This alienation exacerbated the negative outlook on longstanding trends of disaffection toward political representatives and institutions in the country (De Sousa et al. 2014). Notwithstanding that, social protests and strikes increased during the peak of the crisis between 2011 and 2012, with both direct and indirect support of labour unions and political parties at the far end of the left spectrum. ${ }^{4}$ Mobilizations managed to attract public interest over large payroll tax increases, some of which were eventually suspended. ${ }^{5}$

Trust toward national policymakers was progressively eroded during the implementation of the adjustment programme (IMF, 2015; EC, 2016). Data from the Eurobarometer show that between 2012 and 2013 trust in EU and positive influence for national economy decreased tremendously (ec.europa. eu/commfrontoffice/publicopinion/archives/eb/eb79/eb79_first_en.pdf). Negatively affected by the rise of the value added tax, discontent also spread among business sectors, and within party ranks of both government coalition and opposition. The major mainstream party of the opposition, the Ps, decided to stop supporting the government in 2012 by voting against amendments to the 2012 budget and the 2013 budget, at a time when pools on voting intentions gave it an edge over the coalition (De Giorgi et al. 2015). Additionally, the Constitutional Court played a key role in legitimizing distrust and discontent, as several measures were forced to be suspended, such as the Labour Code amendments in 2013 (Decision 602/2013), followed by the Law 27/2014, though that came into force despite the opposition of the labour unions (Cardoso and Branco 2017).

Against this backdrop, IMF and EC stress that the programme should have been better understood and communicated by the national government (IMF 2016). While the communication strategy was failing to gain broader social support, researchers made it clear that the government was keen to

4 For instance, in 2012 the University of Coimbra created the Observatório sobre crises $e$ alternativas (www.ces.uc.pt/observatorios/crisalt), and in the same year civil society launched the Congresso Democrático das Alternativas composed of, inter alia, trade unions' members, left-wing militants, and supporters of social movements (www.congressoalternati vas.org/).

5 Different approaches to the programme led to the approval of Law 23/2012 reforming the Labour Code under the tripartite agreement with UGT, historically linked to mainstream parties, and the opposition of the main labour union CGTP, historically linked to the communist party, calling for general strike. 
persuade society on the need for austerity. The TINA (There Is No Alternative) rhetoric, abundantly adopted by government leaders, was supported by a rich repertoire of arguments shifting blame to both previous administrations and external factors (Fonseca and Ferreira 2015; Moury and Standring 2017). The goal seemed to be that of strengthening its position in the domestic arena and enlarging power of discretion to pass policies hard to be approved otherwise (Cardoso and Branco 2017).

Government strategy, however, resulted in a confidence drop-off $v i s$ - $a$-vis dramatic socioeconomic conditions, rising unemployment (especially among high-profile skilled people), and young generations' flows of migration (De Sousa et al. 2014). Alienation from the political sphere reached the highest abstention rates since 1979 in the 2013 local elections (47.4\%), preceded by $41.9 \%$ in 2011 and followed by $44.1 \%$ of abstention in 2015 in legislative elections ${ }^{6}$. De Sousa and Maia (2017) show that abstention was positively associated with lower socioeconomic resources and educational skills. In this sense, the crisis exacerbated the exclusion of the most vulnerable groups from having influence in public decision (OECD, 2015). ${ }^{7}$

Although mobilizations were perceived as a legitimized way to dissent, scepticism persisted and protests were often perceived as controlled by labour unions and political parties (Observatory for the Quality of Democracy report 2012: www.oqd.ulisboa.pt). As a matter of fact, labour unions were key in the organization of protests and the four general strikes called between 2010 and 2013, as their influence is argued to have limited the affirmation of international claims and connections (Baumgarten 2013). Borders between institutional and non-institutional spheres often blur as activism and politics share, on occasion, the same actors (Accornero and Ramos Pinto 2018). This condition made Portuguese society's reaction to the crisis different from

6 The negative outlook in the evaluation of democratic governance and political representatives' performance grew from 2007 and plunged to critical rates in 2012 (De Sousa et al. 2014; Accornero and Ramos Pinto 2018). The Observatory for the Quality of Democracy Report 2012 shows that the role of European Union and international corporative agencies was extensively criticized as it was seen to interefere with popular sovereignity. Recognition of national coporative groups and labour unions as legitimate partners in political dialogue equally decreased with the general public opinion on their role in the face of the crisis (Balbona and Begega 2015).

7 The Gini coefficient remained stable around 34\% between 2009 and 2014, as social and economic inequality showed severe growth (the extremes of the normal distribution identifying the poorer and the richer were further distanced), and existing asymmetries gained new strength (Rodrigues et al. 2016). 
the disruption of movements and anti-system parties in Spain and Greece. Political parties in Portugal rather tended to incorporate some of the instances claimed by the movements, advancing slow institutional changes and political strategies with few shocks for the system (Afonso et al. 2015).

At the end of the 3-year adjustment programme, Portugal was considered a case of success by IMF, EC, despite the lack of enthusiasm in civil society. ${ }^{8}$ Indeed, the national elections in 2015 expressed the will to reverse the austerity agenda, as its efficacy continues to be questioned at its heart by economists and experts. While IMF recognizes much "fatigue" in the implementation of the programme, data show that the rise of unemployment and poverty exceeded what had been anticipated in the MOU (OECD, 2015). According to some scholars, recessionary effects were influential in securing the neoliberal political agenda imposed by banks and financial institutions, which eventually affected welfare regimes in all Southern European member states in a way that could not be obtained by democratic means (Caldas 2012). These conditions not only broke with corporatist traditions in these countries (Balbona and Begega 2015) but also interrupted secular trends of greater equality and inclusion (Perez and Matsaganis 2017).

\section{CITIZEN PARTICIPATION IN PORTUGAL: RECORD-BREAKING LEVELS}

Social mobilization at the peak of the crisis framed within disaffection toward decision-makers had a unique political momentum in Portugal, little connected by the growth of citizen participation in policymaking, though. The adoption of institutional designs deliberately seeking to engage individuals rather than organized and grassroots groups characterized the diffusion of participatory budgets in the country. While austerity was being implemented, however, neither permeability of the arenas nor forms of erruption occurred within these processes. In Spain, on the contrary, participatory processes

8 The Post-Programme of Surveillance was initiated when Portugal exited the adjustment programme in May 2014 in order to monitor economic, fiscal, and financial policies until at least $75 \%$ of the financial assistance received was repaid. Reports of this programme stress weaknesses in labour market, public administration, and judicial system inter alia. The programme also critically observes the reverse of some previous reforms, such as the return to the 35 hour working week in civil service; the increase of public employment via new hiring policies; the reduction of vaT for food at restaurants; backtracking in reforming state-owned enterprises, and concessions negatively affecting the capacity to attract foreign direct investment. 
opened space to self-organized groups and mass mobilizations, eventually contributing to the formation of new antagonist political subjects (Baiocchi and Ganuza 2016). Likewise, institutional designs in the country tended to encourage individual skills to network and campaign in favour of their ideas in the participatory budgets. These mechanisms may have impaired great participation from the most vulnerable sectors of society, often lacking the necessary resources to have an effective voice in decision-making.

The adoption of institutional designs promoting the engagement of individuals and their capacity to compete with other ideas characterized the diffusion of participatory budgeting in the country. While Latin American practices inspired a first generation of participatory processes in the early 2000s, the initiation of the participatory budget in Lisbon between 2007 and 2008 opened to a massive dissemination in Portugal. The first generation was characterized by consultative mechanisms in small cities, as in the case of the participatory budget of Palmela in 2002 (Sintomer 2005; Sintomer and Allegretti 2009). The empowering discourse promoted by the Brazilian Workers' Party on social justice and state reform was generally replaced by a more paternalistic attitude at this stage (Sintomer and Allegretti 2009). The participatory budget of Lisbon opened an historical phase in which citizen participation was endorsed by both left and right political parties' local agendas (yet with noticeable prevalence for PS-led governments), and individuals were put at the centre of decision-making, with power of proposing and voting.

The Lisbon process allocated 5 million euros for citizen participation until 2012, dropping to 2.5 million euros due to budgetary cuts. Dias (2008) defined this deliberative model as "competition of ideas". Citizens were put at the centre of the process and invited to propose (and vote for) ideas on a one-to-one basis: one citizen, one proposal, and one or more votes. The model clearly relied on the capacity that each citizen had to network and campaign to increase the chances of single projects to be voted on, funded, and implemented ${ }^{9}$. This model has been replicated by most of the municipalities in Portugal, and only a few exceptions have adopted different models of deliberation. In Cascais, for example, citizens are requested to deliberate in public assemblies by shortlisting the proposals to be voted on and imposing

9 The participatory budget in Lisbon was acknowledged by UN-Habitat in 2009 (Cabannes 2009) and OECD in 2010 (OECD 2011, 216) as an effective democratic innovation, and in the same year the Eurocities organization shortlisted this Рв as a notable participatory practice (website: http://www. eurocities.eu/eurocities/eurocities-awards/awards2009). 
the rule of negotiation in round-tables (and reducing the list of proposals to be voted on)..$^{10}$ In Lisbon, other municipal practices have challenged the model of ideas' competition and promoted local partnerships' participation, as in the case of the BipZip. ${ }^{11}$ All in all, the few existing variations to the one-to-one model prove that it continues to be the main reference in the country, as it also was recently adopted in the scaling up of the national participatory budget.

The National Participatory Budget (NPB) was launched as a pillar of the socialist party programme leading the government in coalition with the communist party (PCP) and the left bloc (BE) (Art. 3, Law 42/2016) from 2015. NPB was designed to promote: (i) the quality of democracy; (ii) active and informed participation; (iii) economic and social cohesion (Diário da República n. ${ }^{\circ}$ 21/2017, Série I de 2017-01-30). In the first edition (2017) citizen proposals were made in the 50 local meetings organized by the leading team throughout the country between January and April. Proposals were required to identify the scale of implementation, either national (i.e. involving more than one region) or regional (i.e. involving more than one municipality $)^{12}$, while policy areas included: culture, science, education and adult learning, agriculture, justice, public administration (the last two only in the two autonomous regions of Madeira and Azores). After the analysis of the proposals according to predefined criteria, 38 winning projects that had been voted on (via both online platform and SMS), were publicly presented in September $2017 .{ }^{13}$

10 The participatory budget in Cascais was recently recognized as a best practice by the Global Initiative for Fiscal Transparency (www.fiscaltransparency.net/blog_open_public.php?IdToOpen=5408) and an extensive outlook on its outputs was published in the same year (www.cm-cascais.pt/sites/default/files/ anexos/ge rais/new/2017_op_livro_ingles_final.pdf).

11 The BipZip programme provides a share of around 2 million euros per year on an open competition basis for NGOS and citizens' groups to design and implement urban regenerative projects in critical areas of the city (www.bipzip.cm-lisboa.pt). It was recognized as best participatory practice in 2013 by the International Observatory for Participatory Democracy (www.oidp.net).

12 Regions were distinguished in mainland - North, Centre, Lisbon and Tagus Valley (AML), Alentejo, Algarve - and autonomous - Madeira and Azores. The amount of 3 million euros was distributed into 375,000 euros for national projects; 375,000 euros for regional projects; and 375,000 euros for the two autonomous regions (Azores and Madeira).

13 Proposals could not address infrastructure building; support private service delivery; contravene the national government coalition programme nor the implementation of specific public policies; be technically unattainable; be impossible to translate into a concrete project; exceed a 200,000 euros budget per project. 
For gaining an overview of participatory processes in Portugal today, updated information provided by public authorities is scarce and fragmentary (e.g. it is difficult, and often impossible, to obtain information about the sociodemographic definition of publics and the policies implemented for each process). Despite the impressive number of processes implemented in the country, and the recent implementation of the NPB, few data are available on their performance and outputs, and scientific literature is surprisingly limited on these topics.

The national observatory of participation created by the project Portugal Participa: Caminhos para a Inovação Societal (www.portugalparticipa. pt/Monitoring) can be considered as the main source in this field, as it permits visualizing local processes according to: (i) typology (participatory budget; participatory platform; open presidency; referendum; municipal transparency); (ii) phase (ongoing; suspended; and concluded); and (iii) local authorities. A web search conducted in August 2017 on participatory budgets and participatory platforms resulted in 186 ongoing and 38 suspended participatory budgets, finding only 8 participatory platforms implemented (i.e. practices concerning the involvement of citizens in specific policy areas). These processes occur mainly at the municipal level (around 80\%), including a high percentage of municipalities with fewer than 15,000 inhabitants, while a relatively small share is implemented by parish governments.

CRITICAL TRENDS OF CITIZEN PARTICIPATION IN PORTUGAL

A critical discussion of citizen participation in Portugal should be made in light of the intricate relations between global agencies, national government, and local authorities in the last few years. Critical reflection should be able to explore the influence that transnational and international agencies have had on the spread of participatory processes and their growth during the implementation of the austerity agenda.

The relation between local and global actors of citizen participation can be looked at through the micro-sociological articulation of discourse and practices. The attention paid by some agencies like the UN and the OECD on Portuguese participatory budgets has been extensive since the outset of the participatory budget in Lisbon. This relation implied neither fiscal nor explicit political intervention in the processes, although the role of these agencies in shaping a common discourse on citizen participation cannot be underestimated. 
On the one hand, practices have been awarded for complying with global standards that define what is currently considered as a good practice in citizen participation. On the other, the celebration of their success has most likely reinforced the legitimacy of global discourse (and agents), helping generate expectations and new scenarios, both inside and outside Portugal.

The action of local practitioners, researchers, and social actors is also key to characterize the relation between global and local agents. The opportunities looked for by local agents and opened by international institutions in terms of funding has led to the dissemination of research and/or social innovationoriented projects on citizen participation sincethemid-200os. ${ }^{14}$ Acknowledging the autonomy of research agendas and work-plans of these projects, it is worth highlighting their role in feeding public interest and, on occasion, training public servants and decision-makers in citizen participation. It is emblematic that the national network of municipalities adopting citizen participation (Rede de Autarquias Participativas) was created under one of these projects (Portugal Participa: Caminhos para a Inovação Societal), confirming that neither international funding nor political representatives, third sector, or academia can be taken as an isolated factor in this analysis.

The international endorsement of citizen participation in Portugal started before the peak of the crisis, passed through it, and continues until today. Apart from cuts in some participatory budgets, citizen participation survived almost undisturbed by the turbulent crisis scenario. One of the reasons why the number of processes grew could be related to cuts and reorganization of local authorities under the Mou (Green Paper on Local Administration Reform and the Law 22/2012). ${ }^{15}$ The requirement to review public spending in efficient ways probably drove some local authorities to see participation as an available device to convene on public priorities and minimize risks of

14 The "Participatory Budgeting Portugal" project ("Orçamento Participativo Portugal"), funded by the EQUAL Community Initiative in 2008, was one of the first projects in this field under the leadership of national academia and third sector (www.op-portugal.org). These partnerships have become key in other projects, as in the recent European Union-funded "Empatia" (www.empatia-project.eu) and the EEA grants-funded project "Portugal Participates: roads to societal innovation" ("Portugal Participa: caminhos para a inovação societal") (www.portugalparticipa.pt).

15 The key measures for local authorities under the Mou entailed reduction of administrative units; reduction of state grants (about $60 \%$ of local revenue); reduction of municipality staff by $2 \%$ in 2012 and 2013; decrease of the local debt; reduction of municipal-owned enterprises; new mechanisms for risk management control, reporting, and monitoring (Teles 2016). 
decreasing public legitimacy. Nevertheless, far from representing a "merely" anti-austerity phenomenon, participation continued to grow after the end of the adjustment programme, as proved by recent data and the implementation of the NPB.

This said, why should the relation between international and transnational agencies with national and local decision-makers be considered as intricate? Focussing on the years of austerity, citizen participation, and the agenda imposed by the Troika seemed to work in parallel with little visible interaction or friction. Previous and concurring legitimization provided by projectfunding, practice awards, and other forms of international recognition may have prevented these processes from being dramatically suspended by austerity-led retrenchment measures. However, neither did the Troika seem to consider the expansion of participation in the country as a threat or an opportunity, nor did participatory processes directly address the austerity to, for instance, reformulate their principles and mechanisms. Although Balbona and Begega (2015) argue that attempts were made to reinforce political dialogue with social partners on the austerity guidelines, Teles (2016) mentions that significant consultation with the associations of local authorities would have prevented opposing austerity measures as merely top-down imposed reforms. This evidence mirrors what White (1996) argued: "[i]f participation means that the voiceless gain a voice, we should expect this to bring some conflict. [...] The absence of conflict in many supposedly 'participatory' programmes is something that should raise our suspicions" (White 1996, 15).

The virtual exclusion of austerity from participatory processes, and the absence of reference to opportunities and risks of citizen participation in the Mou should be understood in light of the convergence of global agendas discussed above. More pointedly, comparing critical trends of citizen participation with practices in Portugal, the next sections aim to explore the topic from a critical perspective. Focus on participatory budgets is motivated by their great dissemination and openness in terms of policy areas and publics, which contrasts with either public or issue-based typologies of participation (e.g. the abovementioned participatory platforms, or the BipZip programme).

\section{LOCAL PARTICIPATION}

Regarding the first trend, the implementation of the NPB challenges is argued to be the reduction of participation on the local scale. While so, it is also worth 
highlighting that neither formal nor informal connections exist between NPB and local processes, which means that citizen participation is both promoted and implemented separately on the two scales. In these terms, NPB recalls what Avritzer and Ramos (2016) define as a "weak" form of scaling up citizen participation, one that provides little articulation with local practices, and, hence, contributes little to the creation of a (new) national public sphere. The authors compare this typology to the multi-scale system of delegated and direct participation in Brazil. Acknowledging the challenges that such institutional design posits in terms of state reform, the implementation of the NPB raises some concern about its impact before the proliferation of local processes and, more broadly, on the possibility to reframe citizen participation through a multi-scale approach to policymaking. Without this effort, small interventions risk barely approaching - or even interfering with - current socio-political challenges.

\section{TECHNOCRATIC PARTICIPATION}

Regarding the technocratic trends, hurdles created by the use of technical jargon in public communication, the growth of ICT as a privileged channel of information and participation, and/or the existence of architectural barriers in public meetings increasingly represent a concern for the design of these processes in Portugal. Efforts to identify accessible places for public meetings, as well as the diversification of communication strategies should be noted at both local and national levels. However, the systematic identification of goals of social inclusion and clear definition of their operationalization generally are lacking in participation covenants. Although participatory budgets often conceal enabling measures for the participation of the most vulnerable sectors of the society, risks of discretionary inclusiveness and/or self-organized lobbies are great. When participation is non-binding, the risk is to further exclude citizens with no access to public contention. This trend confirms what Baiocchi and Ganuza (2016) argue about the increasing ambiguity regarding social justice in participatory budgeting worldwide. Given the critical outlooks on country-specific socioeconomic and educational indicators (OECD, 2015; EC, 2016; IMF, 2016), attention to the effective operationalization for higher inclusion of the groups at the margins of society should not be dismissed from a critical analysis of participation in Portugal. 
NON-EVALUATED PARTICIPATION

A critical observation of the expansion of citizen participation in Portugal also raises concerns related to the paucity of accessible data about procedures and outputs. Beyond the responsibility of governments in providing little account on this, the trends discussed above further impair the establishment of a clear demand for accountability to sponsors. The "stepping back" of selforganized society from participatory arenas may have helped downgrade the formation of the demand of public accountability. Font et al. (2014) advocate that "the development of a participatory agenda in local government as the result of movements strongly directed from above without much connection to social pressures is probably correct for Southern Europe" (Font et al. 2014, 62). However, other agents may have played a role in this field. Apart from political representatives and civil servants, academics and practitioners (who had great influence in spreading values and mechanisms of citizen participation in the country) have helped little to enlarge the debate on the evaluation.

\section{CONCLUSIONS}

While in Portugal citizen participation in policymaking has offered a great chance to improve discussion on and practice of democracy at both local and national levels, critical reflection is needed in the light of the international socio-political framework. Blessed by international organizations, the growth of participatory processes continued despite the recent implementation of austerity measures imposed via the international agreement with the Troika. This suggests the existence of an intricate relationship between international and transnational agencies promoting the citizen participation agenda at the global level, and decision-makers in Portugal.

Even though the processes are being implemented on both local and national scales in Portugal, little data and little scientific debate exists on the phenomenon. The discussion provided in this chapter has sought to contrast evidence retrieved from the institutional designs of participatory processes, with focus on participatory budgets, with three critical trends: the detachment of local participatory practices from global issues; the shift toward technocratic approaches in detriment to political-oriented practices; and the scarcity of evaluation in contrast to the mushrooming of pilots. 
In Portugal, regarding the first trend, although the implementation of the national participatory budget challenges international preference for local scale, the weak institutional articulation with the massive presence of local processes may impair goals of effective socio-political changes. About the second trend, models of deliberation focused on the capacity of the individuals to network and campaign without either intermediation or inclusion of organized groups may have favoured the emergence of self-organized lobbies. This dynamic may have had impacts on the participation of the most disadvantaged sectors of civil society, as principles and mechanisms did not directly address austerity as a major issue, and austerity did not seem to interfere with them either. Finally, the absence of evaluation from both local and national institutional designs further limits this reflection, given the lack of data about who is actually participating in these processes. It is expectable that critical assets for research on and accountability of these processes will be posited soon if trends of non-evaluation are not more consistently contested and reversed.

\author{
ROBERTO FALANGA \\ Instituto de Ciências Sociais, Universidade de Lisboa \\ Av. Prof. Aníbal Bettencourt 9-1600-036 Lisboa, Portugal \\ roberto.falanga@ics.ulisboa.pt \\ orcid.org/0000-0002-1059-5509
}

\title{
$\S$ REFERENCES
}

ACCORnero, G., P. R. Pinto. 2018. "Politics in austerity: strategic interactions between social movements and institutional actors in Portugal, 2010-2015". In Portugal and the EU after the Crises, eds. A. C. Pinto, L. N. Rodrigues, and S. Lloyd-Jones. Abingdon: Routledge, forthcoming. AfOnso, A., S. Zartaloudis, and Y. Papadopoulos. 2015. "How party linkages shape austerity politics: clientelism and fiscal adjustment in Greece and Portugal during the eurozone crisis". Journal of European Public Policy, 22 (3): 315-334.

ALves, M., G. Allegretti. 2012. “(In) stability, a key element to understand participatory budgeting: discussing Portuguese cases”. Journal of Public Deliberation, 8 (2), Article 3: http://www.publicdeliberation.net/jpd/vol8/iss2/art3.

ARNSTEIn, S. 1971. "A ladder of citizen participation". Journal of the Royal Town Planning Institute, 57 (1): 176-182.

AVRITZER, L. 2006. "New public spheres in Brazil: local democracy and deliberative politics". International Journal of Urban and Regional Research, 30 (3): 623-637. 
AVritzer, L., A. Ramos. 2016. "Democracia, escala y participación. Reflexiones desde las instituciones participativas brasileñas”. Revista Internacional de Sociología, 74 (3): 1-15.

BAILEY, N., M. Pill. 2011. "The continuing popularity of the neighbourhood and neighbourhood governance in the transition from the 'big state' to the 'big society' paradigm". Environment and Planning C: Government and Policy, 29 (5): 927-942.

Baiocchi, G., E. Ganuza. 2016. Popular Democracy. The Paradox of Participation. Stanford: Stanford University Press.

Balbona, D. L., S. G. Begega. 2015. "Austerity and welfare reform in south-western Europe: a farewell to corporatism in Italy, Spain and Portugal?". European Journal of Social Security, 17 (2): 271-291.

Barnes, M., J. Newman, and H. Sullivan. 2007. Power, Participation and Political Renewal. Case Studies in Public Participation. Bristol: The Policy Press.

Baumgarten, B. 2013. "Geração à rasca and beyond: mobilizations in Portugal after 12 march 2011”. Current Sociology, 61 (4): 457-473.

BOUCHARD, N. 2016. "The dark side of public participation: Participative processes that legitimize elected officials' values”. Canadian Public Administration, 59 (4): 16-537.

Boughton, J. M. 2003. "The IMF and the force of history: ten events and ten ideas that have shaped the institution". IMF Working Paper wP/04/75.

BROWN, D. 2004. "Participation in poverty reduction strategies: democracy strengthened or democracy undermined?". In Participation: From Tyranny to Transformation? Exploring New Approaches to Participation in Development, eds. S. Hickey, G. Mohan. London/New York: Zed Books, 237-251.

BRYSON, J. M., B. C. Crosby, and L. Bloomberg. 2014. "Public value governance: moving beyond traditional public administration and the new public management". Public Administration Review, 74 (4): 445-456.

cabannes, Y. 2009. 72 Perguntas Frequentes sobre Orçamento Participativo. Série Caixa de Ferramentas de Governação Urbana. UN-HABITAT/Iniciativa Comunitária EQUAL. http:// opac.iefp.pt:8o8o/images/winlibimg.exe?key=\&doc=78228\&img $=1156$.

CALDAS, J. C. 2012. "The consequences of austerity policies in Portugal”. Friedrich Ebert Stiftung. http://library.fes.de/pdf-files/id-moe/o9311.pdf.

CARdoso, D., R. Branco. 2017. "Labour market and the crisis in Portugal: no change, U-turn or new departure?”. Working Paper 56/2017 IPRI. http://www.ipri.pt/images/publicacoes/ working_paper/2017_WP/WP_IPRI_56-2017.pdf.

CARPENTIER, N. 2016. "Beyond the ladder of participation: an analytical toolkit for the critical analysis of participatory media processes". Javnost - The Public, 23 (1): 70-88.

CHAVEZ, D. 2008. "The watering down of participatory budgeting and people power in Porto Alegre, Brazil”. Participatory Learning and Action, 58: 57-60.

Christensen, H. S. 2016. "Political dissatisfaction and citizen involvement: political participation in Europe during the early stages of the economic crisis". Partecipazione $e$ Conflitto, 9 (1): 19-45.

CORNWALL, A. 2004. "Spaces for transformation? Reflections on issues of power and difference in participation in development". In Participation: From Tyranny to Transformation? Exploring New Approaches to Participation in Development, eds. S. Hickey, G. Mohan. London/New York: Zed Books, 75-91.

CORNWALL, A. 2008. "Unpacking 'participation': models, meanings and practices”. Community Development Journal, 43 (3): 269-283. 
DAGNino, E. 2004. "Construção democrática, neoliberalismo e participação: os dilemas da confluência perversa”. Política \& Sociedade, 3 (5): 139-164.

DE GIORGI, E., C. Moury, and J. P. Ruivo. 2015. "Incumbents, opposition and international lenders: governing Portugal in times of crisis". The Journal of Legislative Studies, 21 (1): 54-74.

DE SOUSA, L., J. Maia. 2017. “Democracia”. In Portugal Social em Mudança: Retratos Municipais, eds. J. Ferrão, A. Delicado. Lisbon: Instituto de Ciências Sociais, 9-20.

DE SousA, L., P. Magalhães, and L. Amaral. 2014. "Sovereign debt and governance failures: Portuguese democracy and the financial crisis". American Behavior Scientist, 58 (12): 1517-1541.

DE VRIES, P. 2016. “The inconsistent city, participatory planning, and the part of no part in Recife, Brazil”. Antipode, 48 (3): 790-808.

DELEON, P. 1992. “The democratization of the policy sciences”. Public Administration Review, 52 (2): 125-129.

DIAs, N. 2008. Orçamento Participativo: Animação Cidadã para a Participação Política. Projecto Orçamento Participativo Portugal - Mais Participação Melhor Democracia. São Brás de Alportel: São Brás Solidário.

DIAs, N., ed. 2013. Esperança Democrática - 25 Anos de Orçamentos Participativos no Mundo. São Brás de Alportel: Associação In Loco.

DrYZEK, J. 2010. Foundations and Frontiers of Deliberative Governance. Oxford: Oxford University Press.

EC. 2016. Ex Post Evaluation of the Economic Adjustment Programme Portugal, 2011-2014. https://ec.europa.eu/info/publications/economy-finance/ex-post-evaluation-economicadjustment-programme-portugal-2011-2014_en.

EU. 2001. White Paper on European Governance. Available at: http://eur-lex.europa.eu/ LexUriServ/site/en/com/2001/com2001_0428eno1.pdf.

EDER, K. 2014. "The paradox of political participation. Theorizing uncivil society". Partecipazione e Conflitto, 7 (3): 551-575.

FIORINO, D. J. 1990. "Citizen participation and environmental risk: a survey of institutional mechanisms". Science, Technology and Human Values, 15 (2): 226-243.

FONSECA, P., M. J. Ferreira. 2015. “Through 'seas never before sailed': Portuguese government discursive legitimation strategies in a context of financial crisis". Discourse and Society, 26 (6): 682-711.

FonT, J., D. della Porta, and Y. Sintomer. 2014. Participatory Democracy in Southern Europe. Causes, Characteristics and Consequences. London/New York: Rowman \& Littlefield.

GANUZA, E., G. Baiocchi. 2012. “The power of ambiguity: how participatory budgeting travels the globe". Journal of Public Deliberation, 8 (2): Article 8: http://www.publicdeliberation. net/cgi/viewcontent.cgi? article $=1229 \&$ context $=$ jpd.

Gaventa, J., G. Barret. 2010. "So what differences does it make? mapping the outcomes of citizen engagement". Working Paper, Institute of Development Studies, Development Research Centre Citizenship, Participation and Accountability, 347: 1-72.

GOLDFRANK, B. 2012. "The World Bank and the globalization of participatory budgeting". Journal of Public Deliberation, 8 (2): Article 7: http://www.publicdeliberation.net/jpd/ vol8/iss2/art7/.

hajer, M. 2003. "Policy without polity? Policy analysis and the institutional void". Policy Sciences, 36 (2): 175-195. 
HOPPE, R. 2011. "Institutional constraints and practical problems in deliberative and participatory policy making". Policy and Politics, 39 (2): 163-186.

IMF. 2015. Portugal: Selected Issues 15/27, May 2015. Available at: https://www.imf.org/ external/pubs/ft/scr/2015/cr15127.pdf.

IMF. 2016. From crisis to convergence. Charting a course for Portugal. Available at: https://www. imf.org/en/Publications/Departmental-Papers-Policy-Papers/Issues/2016/12/31/FromCrisis-to-Convergence-Charting-a-Course-for-Portugal-43 481.

JESSOP, B. 2002. "Liberalism, neoliberalism, and urban governance: a state-theoretical perspective". Antipode, 34 (3): 452-472.

LEAL, P. A. 2010. "Participation: the ascendancy of a buzzword in the neo-liberal era". In Deconstructing Development Discourse: Buzzwords and Fuzzwords, eds. A. Cornwall, D. Eade. Warwickshire (UK): Practical Action Publishing \& Oxfam.

LEE, C. W. 2015. Do-It-Yourself Democracy. The Rise of the Citizen Engagement Industry. Oxford: Oxford University Press.

LINKE, D. T. 2009. "Democratic participation and the management of scarce resources: the convergence of leftist and neoliberal approaches in times of discontent with the social contract”. Temas de Administração Pública, 4 (5): http://master.fclar.unesp.br/Home/ Departamentos/AdministracaoPublica/RevistaTemasdeAdministracaoPublica/theuer5. pdf.

MIRAFTAB, F. 2009. "Insurgent planning: situating radical planning in the global south". Planning Theory, 8 (1): 32-50.

MOHAN, G., K. Stokke. 2000. "Participatory development and empowerment: the dangers of localism”. Third World Quarterly, 21 (2): 247-268.

MOINI, G. 2011. "How participation has become a hegemonic discursive resource: towards an interpretivist research agenda”. Critical Policy Studies, 5 (2): 149-168.

Mosse, D. 2001. "People's knowledge, participation and patronage: operations and representations in rural development". In Participation: The New Tyranny?, eds. B. Cooke, U. Kothary. London: Zed Books, 16-35.

MOURY, C., A. Standring. 2017. "Going beyond the Troika: power and discourse in Portuguese austerity politics". European Journal of Political Research, 56 (3): 663-679.

NIELson, D. L., M. J. Tierney, and C. E. Weaver. 2006 "Bridging the rationalist-constructivist divide: re-engineering the culture of the World Bank". Journal of International Relations and Development, 9: 107-139.

oECD. 2001. Citizens as Partners. OECD Handbook on Information, Consultation and Public Participation in Policy-Making. Paris: OECD.

OECD. 2009. Focus on Citizens: Public Engagement for Better Policy and Services. Paris: OECD.

OECD. 2011. The Call for Innovative and Open Government. An overview of Countries' Initiatives. Paris: OECD.

oECD. 2015. Reducing Inequality and Poverty in Portugal. Economics department working papers 1258. Paris: OECD.

pateman, C. 1970. Participation and Democratic Theory. London: Cambridge University Press.

PEREZ, S. A., M. Matsaganis. 2017. "The political economy of austerity in Southern Europe". New Political Economy, 22: 1-16.

ROBERTs, N. 2002. "Public deliberation in an age of direct citizen participation". American Review of Public Administration, 34 (4): 315-353. 
Rodrigues, C. F., R. Figueiras, and V. Junqueira (Eds.) 2016. Desigualdade do Rendimento e Pobreza em Portugal: Introdução ao Estudo. Lisbon: Fundação Francisco Manuel dos Santos.

Rosenbaum, W. A. 1976 "The paradoxes of public participation". Administration and Society, $8(3): 355-383$.

Rosener, J. B. 1978. “Citizen participation: can we measure its effectiveness?". Public Administration Review, 38 (5): 457-463.

SINTOMER, Y. 2005. "Los presupuestos participativos en Europa: retos y desafios". Revista del CLAD Reforma y Democracia. http://www.redalyc.org/pdf/3575/3575336 63003.pdf.

sintomer, Y., G. Allegretti. 2009. I bilanci partecipativi in Europa. Nuove esperienze Democratiche nel vecchio continente. Rome: Ediesse.

sмiтh, G. 2009. Democratic Innovations. Designing Institutions for Citizen Participation. Cambridge: Cambridge University Press.

Swyngedouw, E., F. Moulaert, and A. Rodriguez. 2002 "Neoliberal urbanization in europe: large-scale urban development projects and the new urban policy". Antipode, 34 (3): 547-582 .

TELES, F. 2016. "Local government and the bailout: Reform singularities in Portugal". European Urban and Regional Studies, 23 (3): 455-467.

UN. 2014. World's Population Increasingly Urban With More Than Half Living in Urban Areas. New York: United Nations.

Undesa. 2008. People Matter: Civic Engagement in Public Governance. New York: United Nations.

White, S. C. 1996. "Depoliticising development: the uses and abuses of participation". Development in Practice, 6 (1): 6-15.

\section{CITE THIS CHAPTER AS:}

FALANGA, R. 2018. "Critical trends of citizen participation in policymaking. Insights from Portugal". In Changing Societies: Legacies and Challenges. Vol. II. Citizenship in Crisis, eds. M. C. Lobo, F. C. da Silva and J. P. Zúquete. Lisbon: Imprensa de Ciências Sociais, 295-318.

https://doi.org/10.31447/ICS9789726715047.12 